\title{
The Unheard Voices in the Hebrew Bible: The Nameless and Silent Wife of Jeroboam (1 Kgs 14:1-18)
}

\author{
DAVID T. ADAMO (UNISA)
}

\begin{abstract}
This article discusses the story of the Egyptian wife of Jeroboam in 1 Kings 14:1-18. Women are generally marginalized in the Old Testament - in most instances their names are not mentioned, words are not put in their mouths, their achievements are behind the scenes in the narratives. This article is interested in the discussion of the nameless and silent wife of Jeroboam. In the Masoretic (MT), the narrator did not name her despite the dominant and significant role she played in the narrative. However, in the Greek text (Account B), she is identified as "Ano," the daughter of Pharaoh of Egypt. This paper argues that the silence of the wife of Jeroboam in the MT has great meaning and importance in the narrative-it signifies patience, obedience, humility, and self-control. She displayed these characteristics in the face of all the provocation from her husband and the prophecy of the death of her son from the Prophet Ahijah.
\end{abstract}

KEYWORDS: Silence, Namelessness, Old Testament, Kings, Prophet, Obedience

\section{A INTRODUCTION}

The wife of Jeroboam, the king of the northern kingdom of Israel is one of the silent women in the Old Testament. It is indeed very remarkable that even though she was oppressed and abused by her husband, she spoke no word. Although she was the receiver of one of the scariest "rapid-fire prophecies" predicting the death of her son and the destruction of the Northern Kingdom under her husband she did not utter a word. Apart from the fact that she was the mother of a desperately sick son, and a wife of an oppressive and manipulative husband, who kept on commanding her by using blunt imperatives like, "disguise," "go to the prophet," "take specific provisions," she still did not utter a word. Unfortunately, her silence is misunderstood and in other instances receives not attention from interpreters of $1 \mathrm{Kgs} 14: 1-18$.

\footnotetext{
* Submitted: 11/03/2020; peer-reviewed: 17/11/2020; accepted: 03/12/2020. David T. Adamo, "The Unheard Voices in the Hebrew Bible: The Nameless and Silent Wife of Jeroboam (1 Kgs 14:1-18)," Old Testament Essays 33 no. 3 (2020): 393-407. DOI: https://doi.org/10.17159/2312-3621/2020/v33n3a3.
} 


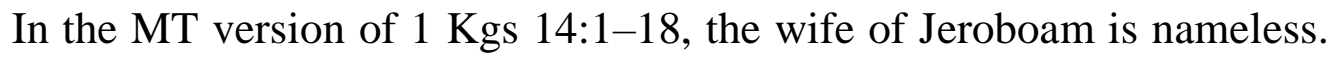
Despite the importance of names, there are so many nameless female characters in Old Testament narratives even though they played huge roles. In total there are about 722 nameless persons in the Old Testament. ${ }^{1}$ The importance of names cannot be overemphasized because their meanings were often directly linked to personal identity. As Rimmon-Kenan argues, a name "unifies the disparate bits of information under one rubric."

Thus, a name is more than just a convenient way of referring to a character in the narrative; and helping to distinguish one character from another especially when characters are overlapping or with similar traits. ${ }^{3}$ However, the namelessness of a character renders readers unable to distinguish the characters from the others by name. ${ }^{4}$ Namelessness effaces personal identity. According to Brenner, the namelessness of female characters does not only efface narrative identity but also symbolizes the suppression of women in the Old Testament. ${ }^{5}$ According to Natanson, the namelessness or anonymity means "the state of being unknown . . . a kind of hiddenness." "From this, one would be safe to conclude that the Old Testament writers appear to be prejudiced against women. This namelessness also has serious implications in the sense that "it affects the readers' point of view, attitude towards the character, and relationship to others' narrative or poetic work."7 The naming and not naming of an individual in the Bible's world "affect the readers' ability to understand the reality the author is pointing." ${ }^{8}$ Unfortunately throughout the account of the MT in 1 Kings 14:1-20

1 Carol Meyers, ed., Women in Scripture (Grand Rapids: Eerdmans, 2000), 173-357.

2 Shlomit Rimmon-Kenan, Narrative Fictions: Contemporary Poetics (London: Methuen, 1983), 39.

3 Joel Weinsheimer, “Theory of Character: Emma," Poetics Today 1 (1979), 195.

4 Adele Reinhartz, Why Ask My Name, Anonymity, and Identity in Biblical Narrative, New York: Oxford University Press, 1998), 10.

5 Athalya Brenner, A Feminist Companion to Judges (Sheffield: Sheffield Academic Press, 1993),13. Brenner observes that while most of the male characters in Judges are given proper names, only four of the nineteen female characters were given names. The namelessness can be a sign of the marginalization of women in the Bible. Peter S. Hawkins and Lesbleigh C. Stahlberg, eds., From the Margins 1, Women of the Hebrew Bible and their Afterlives (Sheffield: Sheffield-Phoenix Press, 2009), xi-xii. Perhaps, the reason for the marginalization is a result of the fact that the Bible is male-centric in its authorship, subject matter, and perspectives. See Jennie Ebeling, Women's Lives in Biblical Times (New York: T \& T Clark, 2011), 8-9.

6 Maurice Natanson, Anonymity: A Study in the Philosophy of Alfred Schutz (Bloomington: Indiana University Press, 1986), 24.

7 Adele Berlin, Poetics and Interpretation of Biblical Narratives (Sheffield: Sheffield Academic Press, 1983, 17-18,59-6170-71, 87-91; Shimon Bar-Efrat, The Art of Biblical Story (Tel-Aviv: Sifriat Poalim, 1979), 64-66.

8 Richard Freud, 'Naming Names: 'Some observation on Nameless women' traditions in the MT, LXX and Hellenistic Literature," SJOT 6/2 (1992), 213-232. 
Jeroboam's wife's name was never mentioned thus denying her the respect and honour due to her. ${ }^{9}$

The purpose of this article is to discuss the meaning and function of the silence of the wife of Jeroboam in 1 Kings 14:1-18, and how her silence is constructed to reveal her obedience, humility, peace, and self-control. These virtues, in my view, make her a woman to emulate in our modern society. To accomplish this, I will discuss the literary analysis of 1 King 14:1-18, the identification, the meaning, and function/importance of her silence in the narrative.

\section{B LITERARY ANALYSIS OF I KINGS 14}

In contemporary biblical scholarship, 1 Kings 14 is often referred to as part of the so-called Jeroboam Cycle, ${ }^{10}$ which somewhat begins with the introduction Jeroboam in $1 \mathrm{Kgs} 11.1 \mathrm{Kgs} 12$ offers an account of the split of Israel's kingdom and of how Jeroboam as a new king of the Northern Kingdom of Israel set up and worshipped a golden calf in Dan and Bethel. Chapter 13 features the prophecy of the man of God against Bethel's altar and the king's order to seize the prophet. As a result, the altar split, and the king's hand shrivelled. However, even though the man of God later healed the king's hand; the man of God was afterwards eaten by a lion because of his disobedience to God.

1 Kings 14 presents an evaluative account of the reign of Jeroboam. The current version is generally considered to be a redaction of an older prophetic story from the school of Ahijah or elsewhere (1 Kgs 11:29-40; I Chron 29:2; 2 Chron13:22). ${ }^{11}$ Two repeated patterns of command-and-fulfillment language provide a frame for the narration (2-6 and $12-18) .{ }^{12}$ According to DeVries, the story has a two-parts structure: ${ }^{13}$ (1)The illness of Abijah reached a crisis point

9 Schneider lamented the fact that women in Genesis are part of someone else story and feature as secondary characters "who are "treated as topics not worthy of their category." However, as Schneider argues "women's roles in the biblical narrative are "more than footnotes to the men" (Tammi Schneider, Mothers of Promise: Women in the Book of Genesis [Grand Rapids, MI: Baker Academic, 2008], 10-11). Gafney, in her examination of women prophets in Ancient Israel, made it clear that women's stories in the Biblical narrative are as important as men's stories (Wilda Gafney, Daughters of Miriam: Women Prophets in Ancient Israel [Minneapolis: Fortress Press, 2008]).

10 David Gooding, “Septuagint's Rival Versions of Jeroboam's Rise to Power (I Kings 11-12)," VT 17 (1967), 173-189; Robin G. Branch, "The Wife of Jeroboam, I King 14:1-18: The Incredible, Riveting, History-Changing of Unnamed, Overlooked, Ignored, Obscure, Obedient Woman," OTE 17 (2004), 157-167.

11 Gina Hens-Piazza, 1-2 Kings (AOTC; Nashville: Abingdon Press, 2006), 139.

12 Hens-Piazza, I-2 Kings, 139.

13 DeVries, 1 Kings, 177. 
that demands urgent resolution; The king sought a favourable revelation concerning his son, Abijah, ${ }^{14}$ by instructing his wife to disguise herself from the prophet; (2) Yahweh reveals to the prophet, Ahijah who announced to Jeroboam's wife that his child will die as soon as she gets home and that the mourning will not only be for her child but also for the entire house of Jeroboam. Furthermore, it is only the child who will be worthy to receive a burial. The prophecy was fulfilled as soon as she got home.

Five characters are noticeable in 1 Kings 14:1-18: (1) Jeroboam, (2) Jeroboam's wife, (3) Abijah, their ill child, (4) the blind prophet, Ahijah (5) and God. The narrator gives a voice and words to Jeroboam, God, and Ahijah, but not Abijah and to the nameless wife of Jeroboam.

Three scenes can be distinguished in the narrative sequence: (1) the meeting between Jeroboam and his unnamed wife (14:1-4a), (2) Ahijah's prophetic declaration (14:4b-16); and (3) the sickness of Abijah and his death (14:17-18). Even though Jeroboam's wife is silent, and seems to be in relation to her husband, she is the one who links the three scenes together.

The narrator presents Jeroboam as having the character of a dictator. Jeroboam commands his men to seize the man of God in $1 \mathrm{Kgs} \mathrm{13:4.} \mathrm{His}$ interaction with his wife is riddled with imperative verbs: "disguise," "go to the prophet," "take specific provisions." Such a sequence of verbs by a speaker denotes "a message of intensity, rapidity, and purposefulness of activities." 15 The narrator purposely imputed these commands to Jeroboam probably to reveal his (Jeroboam's) character as one full of selfishness, manipulation, oppression, and cowardice. Jeroboam treated his wife like a servant with words indicative of "craftiness, discourtesy, abruptness, a command mentality and manipulation."16

From Jeroboam's instruction to his wife in $1 \mathrm{Kgs} \mathrm{14:1-6it} \mathrm{seems} \mathrm{as} \mathrm{if} \mathrm{he}$ was afraid of the prophet Ahijah's condemnation and did not want to face him. The reasons for all these commands are probably "oppression, lack of respect for his wife whom he refuses to name, cowardice, selfishness, manipulation, and

14 The importance of the name that Jeroboam gave to his son should be noticed. His name - which means "my divine father is Yahweh"-has been taken to imply that Jeroboam once loved Yahweh, it also shows that the sickness of his son endangered the dynasty (Donald Wiseman, 1-2 Kings [Tyndale Old Testament Commentaries, Downer Grove: Intervarsity Press, 1993], 30; Hens-Piazza, 1-2 Kings, 139-140). The nature of the sickness is not known. The consultation of the prophet is a common tradition in the

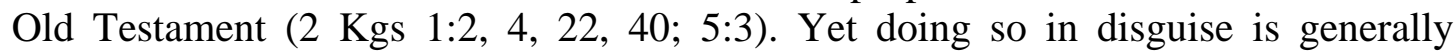
considered to be wrong and ineffective, as was the case with Saul (1 Sam. 28:8), Ahab (1 Kgs 22:30), and Josiah (2 Chr 35:22).

15 Branch, "The Wife of Jeroboam," 157-167; Adamo, "The African Wife of Jeroboam," 71-89.

16 Branch, "The Wife of Jeroboam" 160. 
fear." 17 These fears might be that his hand may shrive again or that the prophet might prophesy doom because he has set up another altar to rival that of Judah. ${ }^{18}$ The prophet being a blind man, Jeroboam thinks that he might not know his wife in her disguise and that she might probably receive a more sympathetic prophecy. ${ }^{19}$

In $1 \mathrm{Kgs} 14: 7-8$ the narrator repeats the language with which Jeroboam

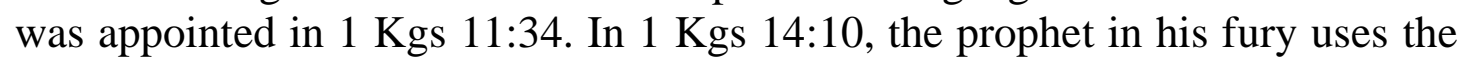
words "helpless and abandoned" which in the Hebrew is "an alliterative phrase of utter loathing". ${ }^{20}$ In $1 \mathrm{Kgs}$ 14:12-16,Jeroboam's wife was instructed to depart immediately with Yahweh's powerful prophecy that when she enters the city, the child will died; however, the child would be the only one who will be buried and mourned Jeroboam's family. ${ }^{21}$ However, in verse 14, Yahweh will raise a substitute as a king for himself. Verse 15 uses vigorous language to describe the doom of Israel: smitten, uprooted, scattered beyond the Euphrates because of the sins of Jeroboam. Verse 16 appears to be more drastic: Yahweh will give up Israel, that is, renounce their election. Verses 11 and 13 predict the non-burial of Jeroboam's heirs which always means to the Jews "the ultimate horror and humiliation."22

Hens-Piazza notices three patterns of structure of the prophetic revelation in $1 \mathrm{Kgs} 14: 7-11:^{23}$

(1) The rehearsal of what God has done for Jeroboam (vv. 7-8).

(2) What Jeroboam has done to God in return (v. 9)

(3) The final pronouncement of what God will do (vv. 10-11).

Branch recognizes the style of the prophetic lawsuit that was used in delivering the messages in such a command tone as if the prophet was reading charges (1 Kgs. 7-10). ${ }^{24}$ Jeroboam, therefore, despite having a name and commanding his nameless wife in so many words, has brought severe judgment on the royal family (10-11). Two "scrupulous ditties," each in a poetic couplet, the first one "with a tricolon and a bicolon," and the second one "with two

17 Branch, "The Wife of Jeroboam, I King 14:1-18: The Incredible, Riveting," 160.

18 Branch, "The Wife of Jeroboam," 160; Adamo, "The African Wife of Jeroboam," 71-89,

19 Adamo, "The African Wife of Jeroboam," 71-89.

20 DeVries, I Kings, 179.

21 Perhaps, the child will be buried because he was still a child. Verses 11 and 13 predict the non-burial of Jeroboam's heirs which always means to the Jews "the ultimate horror and humiliation." DeVries, I Kings, 179.

22 DeVries, I Kings, 179.

23 Gina Hens-Piazza, 1-2 Kings (Nashville: Abingdon Press, 2006), 139-140.

24

Branch, "The Wife of Jeroboam," 162. 
bicolons") (10-11) are pronounced on him. ${ }^{25}$ The first one went as far as to refer to a male person urinating against the wall and comparing "Jeroboam's house to dung." ${ }^{26} 1 \mathrm{Kgs}$ 14: 19-20 is Deuteronomistic and it serves as the closing

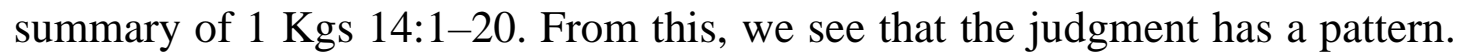
Up to v. 14, it was against Jeroboam and his household. From 1 Kings 14:15, however, it was against the nation of Israel. Here we see the proverbial "switching of gears" from the "micro-level" to the "macro-level", that is, God will strike, scatter and destroy the house of Israel (1 Kgs 14:15). ${ }^{27}$ The reason God will do so is said to be because the people worshipped the Asherah. ${ }^{28}$ Moreover, because Jeroboam made God very angry, his sins became the standard by which the rest of the kings of Israel are judged.

Following the message given her by the prophet, Jeroboam's wife was sent back home to deliver the harsh judgment of the child's death to her husband: "Then Jeroboam's wife arose, and departed, and came to Tirzah. And as she came to the threshold of the house, the child died" (1 Kgs 14:17, NRSV). With reference to gaps in the story itself, the implied audience would possibly have imagined that the "rapid-fire prophecy" surprised the woman. It is possible that they might think of her as breaking down in tears and becoming even more speechless because the man of God commands her to rise and to go home and that her child will surely die and all Israel will mourn him. The death of the child seems to be symbolic of the death of Jeroboam's entire household. ${ }^{29}$ The immediate fulfilment of the judgment, as Branch argues, serves as "a sharp narrative device pointing to the unswerving authority of a monotheistic God who at this instant chooses to communicate his will via the words of the prophet Ahijah."30

\section{THE IDENTIFICATION OF THE NAMELESS AND SILENT VOICE IN 1 KINGS 14:1-18}

If the identification of the wife of Jeroboam is to be based on MT alone, it will be almost impossible because of its silence on the name and place of origin. However, some MT or LXX manuscript traditions do name women which appear only in some manuscript traditions. Richard Freud believes that it is possible that

25 DeVries, I Kings, 178.

26 DeVries, I Kings 16, 178. Deuteronomist quote the two ditties in I Kings 16:4 and 21:21, 24. Deuteronomists also appear to be responsible for the introductory transition of verse 1 which is loosely linked with the preceding story at the beginning. Verses 1516 blames Jeroboam for the exile appears to be a post-Deuteronomistic expansion

27 Branch, "The Wife of Jeroboam", 165.

28 Ibid., 165.

29 DeVries, "I Kings, " 177-178

30 Branch, "The Wife of Jeroboam", 162. 
the addition of names is "a post-biblical interpretative device" and has nothing to do with the integrity of the manuscripts (MT) texts. ${ }^{31}$

The MT of 1-2 Kings contains many nameless women, for example, the wives of Solomon (I Kings 3:1; 7:8; 11:1-3), Pharaoh's daughters (I Kings 11:19-20), Taphenes sister, Hadad's nameless wife and Jeroboam's wife(I Kgs $14: 2,45,6,17)$. The LXX of 1-2 Kgs often contains a different plotline than the MT. Nameless women are especially more visible in the MT versions. ${ }^{32}$ Perhaps, those conflicting and nameless women are for heightening the readers' interests in their influences.

As far as the differences between the MT and LXX texts relating to the so-called Jeroboam Cycle (Account A and B and the MT) are concerned, a few remarks are in order. ${ }^{33}$ There is no consensus among scholars as to which is the original and more authentic. Some consider the Hebrew text as more original than the Greek text. ${ }^{34}$ Others believe that the Greek text is more authentic and original than the Hebrew. ${ }^{35}$ Accounts A and B in the Greek agree against MT, on one point, that is, the return of Jeroboam to Sareirra when he heard the news of Solomon's death. However, according to the MT Jeroboam was invited to the

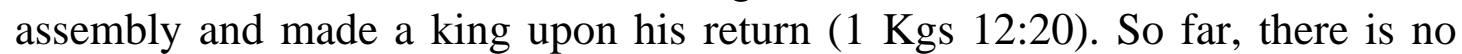
satisfactory "literary analysis of the three versions of these accounts that would explain fully both the literary interrelationships between the three versions and the specific hermeneutical agendas that each is designed to pursue". ${ }^{36}$

The case of 1-2 Kings concerning nameless women is more complex than other books of the Old Testament, as have been discussed by several scholars. ${ }^{37}$ While the MT (1 Kgs 14:2, 4, 5, 6 and 17) features only a nameless wife of King

31 Freund, "Naming Names."

32 This is not to say that they are not present in the other books of the Old Testament.

33 Robert P. Gordon, "The Second Septuagint Account of Jeroboam: History or Midrash," VT 25 (1975), 368-393.

34 Marvin A. Sweeney, I \& II Kings (Louisville: Westminster John Knox Press, 2007), $165-195$.

35 John Gray. I and 11 Kings (London: SCM Press, 1964), 279; James Montgomery, A Critical and Exegetical Commentary on the Book of Kings (Edinburg: T \&T Clark, 1951), 248.

36 Adrian Shenker, "Jeroboam's Rise and Fall in the Hebrew and Greek Bible," JSJ 39 (2008): 367-373.

37 James D. Shenkel, Chronology and Recessional Development in the Greek Text of Kings (Cambridge: Cambridge University Press. 1968); Marcos Fernandez, "The Lucianic Text in the Book of Kingdoms: From Largarde to the Textual Pluralism." De Septuaginta Studies in Honor of John William Wevers on His Sixty Fifth Birthday. Edited by A Pietersma and C. Cox. Mississauga: Benben Publications 1984), 161-174; Emmanuel Tov, "Criteria for Evaluating Textual Readings: The Limitation of Textual Rules," HTR 75 (1982): 429-448. 
Jeroboam, we have an LXX B version refer to her as Ano with additional information linking her to another story:

And Jeroboam heard in Egypt that Solomon was dead, and he spoke in the ears of Susakim king of Egypt. And Susakim gave to Jeroboam, Ano the elder daughter of Kimmina his wife to be his wife; She was great among the daughters of the king and she bore to Jeroboam Abia his son... And his young child was sick with severe sickness and Jeroboam went to enquire concerning the child and he said to Ano his wife, arise go enquire of God concerning the child... (3 Kgs 12:24, NRSV).

The LXX in $3 \mathrm{Kgs} 11: 14,25$ also contains another account of possibly of the same Pharaoh, King of Egypt concerning Hadad and his wife. What this probably means is that the two LXX versions have fuller, more expansive traditions about unnamed women of the MT. ${ }^{38}$ While the MT and accounts A of the Greek text were, therefore, silent about the name of the wife of Jeroboam, account B of the Greek text identify her not only as Ano but also refer to her country of origin as Egypt in Africa. ${ }^{39}$ In this regard, it seems that there is some relative evidence of credibility in this fact. Although the MT and Account A of the Greek text are silent about the name and the place of origin of the wife of Jeroboam, the MT account of Jeroboam's running for his life to Egypt during the time of Pharaoh Shishak seems to support Account B concerning the name and the place of origin of Jeroboam's wife as Egypt.

According to Richard Freud, the Greek version probably does not reflect an interpretation or commentaries, but possibly means loner traditions about women "whose names were not known to the MT or whose names were ignored, excluded or not transmitted by the scribal tradition from which the MT was written." ${ }^{40}$ It is also possible that the MT did not have any sensitivity to women's traditions or issues. ${ }^{41}$ That may be the reason why the wife of Jeroboam is nameless and the silent..

What appears important to us, however, is that there exists a Greek Bible which mentioned specifically Ano as the name of the wife of Jeroboam whose home is Egypt in Africa, even if the Hebrew texts were silent about it.

If the text is assumed as containing some historical data which was later narrated for purposes beyond chronicling events, one might suggest that perhaps, as Hadad escaped to Egypt in Africa and pleaded with Pharaoh to allow him to return home because David had died (I Kgs 11:21f), so also Jeroboam escaped

38 Freund, "Naming Names," 231-232.

39 Adamo, "The African Wife of Jeroboam." TV 37/2 (2013): 71-89.

40 Richard Freud, "Naming Names," 231.

41 Ibid. 232. 
to Egypt in Africa and sought permission to return to Israel after Solomon's death. If this was the case, then it might also be that Jeroboam likely contracted a diplomatic marriage with one of Pharaoh's princesses while he sojourned in Egypt. Considering international political relations at the time, it is also very likely that Jeroboam's wife is one of the daughters of Pharaoh given to him for a wife before he left Egypt. Within the broader Old Testament context, we may note that there are three princesses of Pharaohs referred to as daughters of Pharaohs in the Old Testament. The first one is the nameless daughter of Pharaoh who is the oppressor of the children of Israel (Ex 2:5-10). The second one is one called Bithiah, one of the two wives of Mered of the unnamed Pharaoh (I Chron. 4:18). ${ }^{42}$ The third one is the wife of Solomon (I Kgs 3:1, 7:8 and 8:24). On this reading then, Ano, the wife of Jeroboam was probably assumed to be the fourth daughter of Pharaoh (Shishak) mentioned in the Old Testament (1 Kings 14:118).

\section{THE MEANING AND FUNCTION OF SILENCE}

In the Egyptian Instruction of Ptahhotep, which is regarded as the oldest book in the world, ${ }^{43}$ silence is regarded as a virtue. ${ }^{44}$ In the book, Ptahhotep was advising his son who will eventually replace him as vizier. His advice was divided into 37 passages called "maxims." Egyptian wisdom advises one's reaction in three situations: (1) the equal opponent (2) the greater opponent, and (3) one's opponent who is inferior. According to this ancient wisdom, in each case silence, the refusal to speak is the best reaction. ${ }^{45}$ It is an effective way of prevailing in a dispute. Silence is a case of doing nothing, and a case of not speaking. It is the most effective action. It is the best action and what makes it the best action is the way it communicates different things in different circumstances. In a case where one opponent is of superior social standing silence communicates humility by submission ("bend your arms, bow your back);" when one's opponent is of the same status, silence communicates superiority. But when one's opponent is of

42 Susan T Hollis, "Bithiah," in Women in the Scripture: A Dictionary of Named and Unnamed Women in the Bible, the Apocryphal/Deuterocanonical Books and the New Testament. (Carol Meyers (ed), Michigan: William B Eerdmans Company,2000), 6061.

43 Ptahhotep is a vizier or chief minister in Egypt during the fifth dynasty of the 25 or $24^{\text {th }}$ century. It is regarded as one of the most famous and influential instructions in the ancient Egyptian wisdom tradition (James Pritchard, Ancient Near Eastern Text Relating to the Old Testament [Princeton: Princeton University Press, 1969], 412-414). ${ }^{44}$ Chike Jeffers, "Silence as a Virtue: A Study in the History of Ancient African Philosophy,"

https://www.academia.edu/27876095/Silence_as_a_Virtue_A_Study_in_the History of_Ancient_African_PhilosophyAccess Date: 23/2/2020. Translated by Parkinson, 252.

${ }^{45}$ Jeffers, "Silence as a Virtue.". 
low social status; silence communicates one's ability to calmly ignore evil speech. Silence is self-control. What makes silence to be superbly effective action has to do with what it communicates.

In some cultures, silence is embraced as important virtue. Since a culture 'is an immensely intricate series of complexes, sound, and silence... are the most important complex in live culture." ${ }^{46}$ Different kinds of silence are identified in paralinguistic phenomena: "hesitation silence," and "interactive silence." ${ }^{47}$ All these are part of a culture and used to communicate culture.

The wife of Jeroboam too did not speak to any of the characters. Her and the sick child's silence constitute a difficult task to identify. What is certain however is that silence is meant to communicate some important things in the narrative. Why did she not utter a word herself? Or why did the narrator refuse to put a word in her mouth? Did she deliberately keep silent on her own? Was she keeping quiet because of her inferiority as a wife and as an African? A more important question is, does her silence communicate some things in the whole discussion?

Certainly, she is not keeping quiet because of any inferiority complex as a wife or as an African. The examination of the biblical texts that mention Africa and Africans in the biblical world did not hold any prejudice against any black people in their midst becausenof the colour of their skin. Prejudice towards people with black skin colour is certainly post-biblical and alien to ancient Israel. ${ }^{48}$ The narrator may not be the one who deliberately refuses to put words in

46 Grace Adamo, "Silence as a Message Conveying Process: A Study of Yoruba Speakers of English in Nigeria," IJC 17/1, (2007): 91-99; Fernando Poyates, New Perspective in Nonverbal Communication, (New York: Pergamon Press, 1983),218.

47 Thomas Bureau, "Communication Silences: Forms and Functions." The Journal of Communication, 23, (1979), 26; Poyates, "New Perspective," 231; Adamo "Silence as a Message Conveying Process," 92.

48 The Old Testament people did not in any way despise the people called "Cushites" or "Egyptians." Instead, they were viewed as faithful people (Ebed-Melech in Jr 38:614; 39:16-18), strong and reliable (Tirhakah), and people worthy of great esteem. The use of black Africa as a valuation for Israel's action demonstrates the great value attached to them during the biblical period. The frequent mentioning of Cushites and Egyptians demonstrates the deep knowledge, familiarity, and respect the biblical and ancient people, have for them (David Adamo, "The portrayal of Africa and Africans in the book of Jeremiah,"In die Skriflig51/1 [2018]: 1-9; "Reading Jeremiah 13:23 in an African context,' JSem23/4 [2014]; 500-530; “Africa and Africans in the Old Testament and its environment" [PhD Dissertation, Baylor University, 1986]; Charles B Copher, 'The black man in the biblical world," JITC 1 [1985]: 17-16; Randall Bailey, "Beyond the identification: The use of Africans in the Old Testament poetry and narratives in Stony the road we trod [ed. C.H. Felder; Minneapolis: Fortress Press, 1991]165-184; Rodney Sandler, Jr., "Can a Cushite change his skin? Cushites, racial 
her mouth (no one is sure). It is possible that she deliberately kept silent on her own in other to communicate some important things and to demonstrate wisdom as taught in ancient Egypt her possible place of origin. This is because silence is a message conveying process. To know the message that her silence communicates, it is important to understand that silence is a cultural element that has conversational functions and values as mentioned above. ${ }^{49}$ When silence is viewed semiotically and in many African contexts, it has functions, values, and meanings. ${ }^{50}$ Among the Yoruba people of Nigeria, for example, silence does not mean stupidity neither does it mean that one is not communicating. Silence can mean approval or disapproval. Silence can communicate anger, frustration, confusion, and displeasure, annoyance or indifference or sorrow. From this, one can say that silence in Africa is similar to that of the culture of ancient Israel especially when it has something to do with the marginalisation of women by husbands and constituted authorities. Sometimes, silence hurts more than words during a period of indignation.

From the above, one can conclude that the wife of Jeroboam's silence can also mean approval and obedience. She was commanded by Jeroboam, her husband to "disguise," "go to the prophet," "take specific provisions," but she did not say a word in reply.

Without a word, she links Jeroboam and Ahijah as an intermediary and sets in motion the familiar and national prophecy." "When she leaves home, she represents Jeroboam and when she gets back home, she represents Ahijah. She obeys the commands of both the husband and the prophet without remonstration. The silent wife of Jeroboam first acts as a messenger of Jeroboam and Ahijah, the blind prophet. ${ }^{51}$

The silence of the wife of Jeroboam sheds light on the prophet Ahijah's and Jeroboam's character. Jeroboam shows a manipulative character. The theme of obedience which the silence of Jeroboam's wife demonstrates is an important one in Jeroboam's cycle. The silent and unnamed woman/wife of Jeroboam obeys her husband and the prophet Ahijah without question and returns home while many modern women would have disobeyed the prophet's instruction with the possibility of saving her son. One is tempted to ask many questions. Why did she go back home knowing that her son would die when she reaches home according to I Kgs 14:17? Did she not believe that the word of the prophet would

othering, and the Hebrew Bible,"Interpretation 60/4 [2006]: 401-426; Victor Matthews, The Hebrew prophets and their social world[Grand Rapids: Eerdmans, 2012]; John A. Thompson, The book of Jeremiah, New International Commentary on the Old Testament[Grand Rapids: Eerdmans, 1980]).

49 Adamo, "Silence as a message." 91-98.

50 Ibid., 91-98.

51 Adamo, "The African Wife of Jeroboam," 71-78; 
come to pass? Why did she not seek to avert the fulfilment of the prophetic words by repentance or going another direction?

The answer to the questions above appear to be a mystery. However, we can deduce that it was probably because of her obedience. Moreover, at another point, her silence can be taken to mean anger, frustration, confusion, annoyance, displeasure, sorrow, and retaliation. Her silence during the command of her husband is probably an attempt to retaliate. Sometimes, as much as silence is golden, it can hurt more than words during a period of indignation, especially during a period of abuse or oppression.

When she got to the prophet Ahijah, despite his blindness, he was able to recognise her with her disguise. He delivers God's judgment. Such judgment was scary and discouraging. The prophet said that God will destroy and scatter the children of Israel. The sick child Abijah will die and Jeroboam's family will be annihilated from the land. Such a prophecy of doom may have been surprising to Jeroboam's wife and likely came as a shock, which brought her confusion, anger and frustration. She probably went into a state of silence as she wondered how she would be able to deliver such prophecy of doom. She was indeed sorrowful. Her silence may mean sorrow.

Furthermore, Jeroboam's wife's silence should be viewed as encompassing compassion and courage. What her husband could not do, she did it. Imagine if she had argued and disobeyed her husband and the prophet. Perhaps, she believed that her silence means peace and wisdom and she acted accordingly. Even though she knew that her husband and entire Israel had sinned and, therefore, may receive a bad judgment, she had compassion for her husband and the sick child. That may have been the reason why she summed up the courage to go to the prophet. Her silence made her a woman of courage and compassion.

\section{E CONCLUSION}

In this article, it was argued that the nameless and silent wife of Jeroboam could be linked to one of the daughters of Pharaoh from Egypt according to Account B Greek text which gave her name as "Ano." In this African context, and with Egypt being associated with wisdom in many Old Testament texts, the identity and silence of Jeroboam's wife take on a new meaning. Her silence not only means obedience, approval, and disapproval, but also confusion, frustration, sorrow, annoyance, displeasure, and anger. It also means compassion, courage, and humility the importance of the wife of the king or of women in general. ${ }^{52} \mathrm{On}$

52 Adele Berlin, "Wife of Jeroboam." 
the contrary, despite her silence, the narrative accords her more importance, dignity, and relevance than her husband who is characterised as a bully. ${ }^{53}$

When this is re-read from a Christian ethical perspective, one could then look at the silence of Jeroboam's wife as a virtue, but with a different nuance. When provoked, silence is a difficult thing, but the wife of Jeroboam also known as Ano can be interpreted as exhibiting dignity. ${ }^{54}$ By no means must this be misunderstood as encouraging women to be silent and passive in contexts of abuse or at any other time when it is necessary and wise to speak. On the contrary, even in the MT version of the narrative, the sound of silence of Jeroboam's nameless wife was more effective at revealing the divine will than her husband's noise and fury, all of which ultimately signified nothing and noone.

\section{F BIBLIOGRAPHY}

Adamo, David T., "The African Wife of Jeroboam.” Theologia Viatorum 37/2 (2013): 71-89.

. "The portrayal of Africa and Africans in the book of Jeremiah." In die Skriflig

51/1, (2018) a2259. DOI: https://doi. org/10.4102/ids.v51i1.2259, 2018.

. "Reading Jeremiah 13:23 in an African context." Journal for Semitics 23/2 2014): 500-530.

"Africa and Africans in the Old Testament and Its Environment." $\mathrm{PhD}$ dissertation: Baylor University, 1986.

Adamo, Grace, "Silence as a Message Conveying Process: A Study of Yoruba Speakers of English in Nigeria." International Journal of Communication 17/1 (2007): 9199.

Bailey, Randall. "Beyond the Identification: The Use of Africans in The Old Testament Poetry and Narratives," Pages 165-184 in Stony the Road We Trod. Edited by C. H. Felder. Minneapolis: Fortress Press, 1991.

Bar-Efrat, Shimon. The Art of Biblical Story. Tel-Aviv, Sifriat Poalim, 1979.

Berlin, Adele. "Wife of Jeroboam." Pages 271-272 in Women in the Bible, the Apocryphal/Deuterocanonical Books and the New Testament. Edited by Carol Meyers. Grand Rapids: Eerdmans, 2000.

- Poetics and Interpretation of Biblical Narratives Sheffield: Sheffield Academic Press, 1983.

Branch, Robin G. "The Wife of Jeroboam, I King 14:1-18: The Incredible, Riveting, History-Changing Significance of Unnamed, Overlooked, Ignored, Obscure, Obedient Woman." Old Testament Essays 17 (2004): 157-167.

."A Case of Spouse Abuse? A Study of the Marriage of Jeroboam (I King 14:18)."Old Testament Essays 22/2 (2009): 253-280.

Brenner, Athalya,"Introduction." Pages 13-16 in A Feminine Companion to Judges. Edited by Carol Meyers. Sheffield: Sheffield Academic Press, 1993.

53 Branch 2009:277

54 LaVerne Gill, Daughters of Dignity (Cleveland, Ohio: Pilgrim Press, 2000). 
Bureau,Thomas. "Communication Silences: Forms and Functions." The Journal of Communication 23 (1979): 117-146.

Copher, Charles B. "The Black Man in the Biblical World." Journal of the Interdenominational Theological Center 1(1985): 17-16.

DeVries, Simon. I Kings. Word Bible Commentary. Waco: Words Publication, 1985.

Ebeling, Jennie. Women's Lives in Biblical Times. New York: T \& T Clark, 2011.

Fernandez, Marcos. "The Lucianic Text in the Book of Kingdoms: From Largarde to the Textual Pluralism." Pages 161-174 in De Septuaginta Studies in Honor of John William Wevers on His Sixty Fifth Birthday. Edited by A Pietersma and C. Cox. Mississauga: Benben Publications 1984.

Freud, Richard. "Naming Names: 'Some Observations on Nameless Women' Traditions in the MT, LXX and Hellenistic Literature." Scandinavian Journal of Old Testament 6/2 (1992): 213-232.

Gafney, Wilda. Daughters of Miriam: Women Prophets in Ancient Israel. Minneapolis: Fortress Press, 2008.

Gill, Laverne. Daughters of Dignity. Ohio: Pilgrim Press, 2000.

Gooding, David W. 'Septuagint's Rival Versions of Jeroboam's Rise to Power (I Kings 11-12)." Vetus Testamentum 17 (1967): 173-189.

Gordon, Robert P. "The Second Septuagint Account of Jeroboam: History or Midrash." Vetus Testamentum 25 (2000): 368-393.

Gray. John. I and 11 Kings. London: SCM Press, 1964.

Hawkins, Peter.S, and Stahlberg, Lesbleigh C., eds. From the Margins 1, Women of the Hebrew Bible and Afterlives, Sheffield: Sheffield-Phoenix Press, 2009.

Hens-Piazza, Gina. 1-2 Kings. Abingdon Old Testament Commentaries. Nashville: Abingdon Press, 2006.

Hollis, SusanT. "Bithiah." Pages 60-61 in Women in the Scripture: A Dictionary of Named and Unnamed Women in the Bible, the Apocryphal/Deuterocanonical Books and the New Testament. Edited by Carol Meyers. Michigan: Eerdmans. 2000.

Jeffers, Chike. "Silence as a Virtue: A Study in the History of Ancient African Philosophy."

https://www.academia.edu/27876095/Silence_as_a_Virtue_A_Study_in_the_Hi story_of_Ancient_African_Philosophy. Access Date: 23/2/2020. Translated by Parkinson, 252.

Matthews, Victor. The Hebrew Prophets and Their Social World. Grand Rapids: Baker Academic, 2012.

Meyers, Carol, ed. Women in Scripture. Grand Rapids: Eerdmans, 2000.

Montgomery, James. A Critical and Exegetical Commentary on the Book of Kings. Edinburgh: T \& T Clark, 1952.

Natanson, Maurice. Anonymity: A Study in the Philosophy of Alfred Schutz. Bloomington: Indiana University Press, 1986.

Poyates, Fernando. New Perspective in Nonverbal Communication. New York: Pergamon Press Inc., 1983.

Pritchard, James. Ancient Near Eastern Text Relating to the Old Testament. Princeton: Princeton University Press, 1969.

Reinhartz, Adele. 'Why Ask My Name? Anonymity and Identity in Biblical Narrative. Oxford University Press, New York, 1998. 
Adamo, “The Unheard Voices," OTE 33/3 (2020): 393-407 407

Rimmon-Kenan, Shlomit. Narrative fictions: Contemporary Poetics. London: Methuen, 1983.

Sandler, Rodney, Jr. "Can a Cushite Change His Skin? Cushites, Racial Othering, and The Hebrew Bible.” Interpretation 60/4 (2006): 401-426.

Schneider, Tammi. Mothers of Promise: Women in the Book of Genesis. Grand Rapids: Baker Academic, 2008.

Shenker, Adrian. "Jeroboam's Rise and Fall in the Hebrew and Greek Bible." Journal for the Study of Judaism39 (2008): 367-373.

Shenkel, James D. Chronology and Recentional Development in the Greek Text of Kings. Cambridge: Cambridge University Press. 1968.

Sweeney, Marvin A. I \& II Kings. Louisville: Westminster John Knox Press, 2007.

Thompson, John A. The book of Jeremiah, New International Commentary on the Old Testament. Grand Rapids: Eerdmans, 1980.

Tov, Emmanuel. "Criteria for Evaluating Textual Readings: The Limitation of Textual Rules." Harvard Theological Review 75 (1982): 429-448.

Weinsheimer, Joel. "Theory of Character: Emma." Poetics Today 1 (1979).

Wiseman, Donald. 1-2 Kings. Tyndale Old Testament Commentaries. Downer Grove: Intervarsity Press, 1993.

Professor Adamo, Davit T. Research Fellow at the Department of Biblical and Ancient Studies of University of South Africa.E-mail:adamodt@yahoo.com. ORCID: http://www.0000-0001-8610-4289. 